\title{
Stem cell therapy for tendon and ligament injuries in the horse - technique and outcome
}

\author{
Roger K. W. Smith \\ The Royal Veterinary College, North Mymms, UK
}

\begin{abstract}
Summary
The technique involves the collection of bone marrow from the sternum in the standing sedated horse, followed by isolation and expansion of the nucleated adherent cell population (containing the MSCs) in the laboratory. After approximately 2-3 weeks, in excess of 10x106 cells are available for implantation. The cells are suspended in bone marrow supernatant as this has been found to have a beneficial mix of growth factors and then implanted under ultrasonographic guidance into the core lesion of the tendon or ligament under standing sedation. The horses then enter an ascending exercise regime aimed at providing a controlled mechanically appropriate (tension) environment for the cells. Outcome data for horses followed for 3 years show a greater than $50 \%$ reduction in re-injury rate $(p<0.05)$ for National Hunt racehorses when compared with published outcome for the same discipline of horse followed for the same period.
\end{abstract}

Key words: Stem cell therapy, tendon, ligament, injury, tendonitis, technique, outcome, horse

\begin{abstract}
Stammzelltherapie bei Sehnen- und Bandverletzungen des Pferdes - Technik und Ergebnis
Die Technick der Stammzelltherapie beginnt mit der Gewinnung von Knochenmark aus dem Sternum am stehenden, sedierten Pferd gefolgt von der Isolation und Vermehrung kernhaltiger Zellpopulationen im Labor. Nach ungefär 2-3 Wochen stehen so mehr als $10 \times 10^{6}$ Zellen für die Implantation zur Verfügung. Die Zellen werden in Knochenmarksüberstand suspendiert, weil sich so ein vorteilhafter Mix aus Wachstumsfaktoren ergibt. Anschließend werden die Zellen unter Ultraschallführung am sedierten Pferden in die Kernläsion der betroffenen Sehnen oder Bänder implantiert. Danach beginnen die Pferde mit einem Bewegungsprogramm mit dem Ziel, die implantierten Zellen einem angemessenen biomechanischen Bewegungsreiz auszusetzen. Die Ergebnisse über einen Zeitraum von 3 Jahren zeigen für National Hunt Rennpferde im Vergleich zu anderen publizierten Ergebnissen für die gleiche Disziplin und den gleichen Zeitraum eine um 50\% reduzierte Rückfallrate $(p>0,05)$.
\end{abstract}

Schlüsselwörter: Stammzelltherapie, Sehne, Band, Verletzung, Tendinitis, Technik, Ergebnis, Pferd

\section{Introduction}

The use of mesenchymal stem cells (MSCs) for the treatment of tendon and ligament overstrain injuries in the horse has now become established (Smith et al 2003). The science underpinning the use of this technology is presented in a previous paper. Two techniques exist - one that utilises cells derived from adipose tissue taken from the tail head and the other using MSCs derived from a bone marrow aspirate. The former does not involve a culture step and so is a heterogenous mix of cells (estimated at containing 2\% MSCs). The latter involves a 3 week culture period where the number of MSCs are enriched and expanded prior to implantation. This paper will describe the technique for the treatment of tendon and ligament overstrain injuries in the horse using bone marrow-derived cells and report the current outcome data for horses treated in this way.

\section{Materials and Methods}

Case selection

The selection criteria of cases considered suitable for treatment with MSCs are horses with a hypoechoic lesion within any of the palmar soft tissue structures of the distal limb, contained by intact peripheral tendon/ligament or paratenon. In addition, the lesions should be of recent onset - preferably referred within 1 month of injury and ideally not later than 2 months after injury, although if a hypoechoic lesion is still evident, these are potentially still treatable. Suspensory ligament injuries are frequently treatable at later stages than superficial digital flexor tendon injuries. After this time point, significant fibrosis will have already occurred prior to implantation which will (a) make implantation more difficult, (b) persistent hypoechoic needle tracts can remain for a prolonged period of time in these cases, and (c) reduces the benefits of the stem cell therapy. Generally recurrent injuries should be avoided for the same reasons - i.e. there will already be significant fibrosis present. However, recurrent severe injuries (e.g. ruptures) where there are areas of such severe pathology that the repair of that area will dominate the prognosis, then these cases would also be suitable.

\section{Bone marrow aspiration}

As the bone marrow has to be transported to the laboratory after it is obtained, aspirations should only be done on a Monday-Thursday to avoid prolonged delivery over weekends. The horse is first sedated with a combination of $\alpha 2$ agonist and opiate (e.g. detomidine $\mathrm{HCl}$ and butorphanol). $\mathrm{A}$ $10 \mathrm{~cm}$ wide band overlying the sternum is clipped and scrubbed with surgical scrub (e.g. chlorhexidine) and surgical spi- 
rit. The sternum is examined ultrasonographically to identify the three most caudal sternebrae by the appearance of their intersternebral spaces (figs 1 and 2). The most caudal one is avoided as it is thinner and hence penetration of its deeper surface is easier. The position of these intersternebral spaces is marked on the adjacent hair with a marker pen (fig 3).

The area of the sternum is prepared aseptically and local anaesthetic placed at the predicted aspiration entry points to

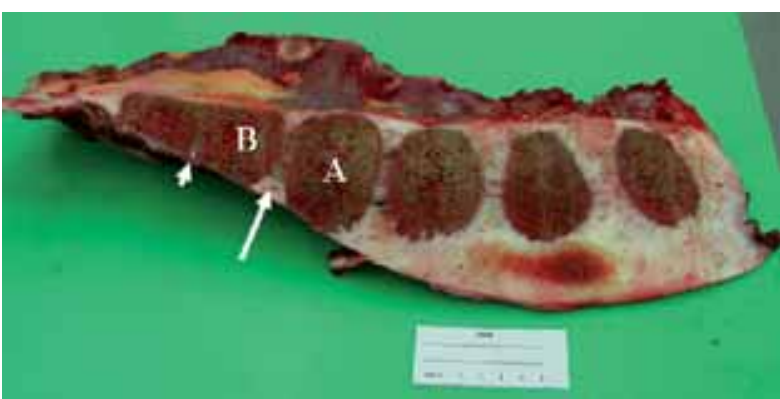

Fig 1 - Longitudinal section of sternae (caudal to the left). Usually there is a smaller intersternebral space between the most caudal two sternebrae (short arrow) and a more prominent space seen ultrasonographically as a $V$-shaped defect (long arrow; fig 2). The sternebrae marked ' $A$ ' and ' $B$ ' are those aspirated routinely because the most caudal one is thin and there is an increased risk of penetration, and the more cranial sternebrae are covered by a bony prominence. Längsschnitt durch das Brustbein (links=caudal). Gewöhnlich befindet sich zzwischen den beiden letzten sternebrae ein kleinerer Zwischensternalspalt (kurzer Pfeil) und ein etwas auffälligerer Spalt zeigt sich sonographisch als V-förmiger Defekt (langer Pfeil; Abb. 2). Routinemäßig wird aus den beiden mit ' $A$ ' und ' $B$ ' markierten Sternebrae aspiriert, weil der letzte dünn ist und die Gefahr der Penetration besteht und der cranial gelegene von Knochensubstanz bedeckt ist.

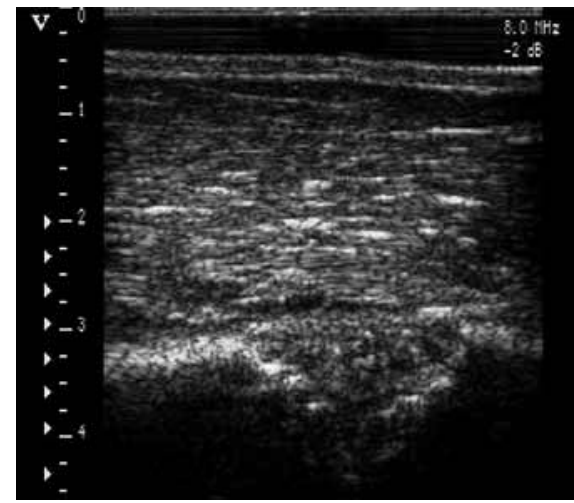

Fig 2 - The ultrasonographic appearance of the intersternal space between sternebrae $A$ and $B$ shown in figure 1. This space is usually level to the caudal aspect of the elbow.

Sonographische Darstellung des Intersternalspalts zwischen den Sternebrae $A$ und $B$ aus $A b b .7$.

aspirate bone marrow from sternebrae $A$ and $B$ shown in figure 1. Prior to aspiration, syringes are pre-loaded with heparin (to give a final concentration of $250 \mathrm{iu} / \mathrm{ml}$ bone marrow). Commonly a $10 \mathrm{ml}$ syringe is pre-loaded with $0.5 \mathrm{ml}$ of a $5000 \mathrm{iu} / \mathrm{ml}$ heparin solution into which $9.5 \mathrm{ml}$ bone marrow is aspirated.

The area is then scrubbed a final time before a small stab incision is made through the skin with a No. 11 scalpel blade. The Jamshidi needle is introduced through the stab inci- sion and advanced until it contacts with the ventral surface of the sternebra in the mid-line (fig 4). The index finger is placed $2 \mathrm{~cm}$ from the skin surface on the needle shaft and the needle gradually advanced using rotating movements until the index finger is against the skin surface. This ensures the needle does not penetrate the deep surface of the sternebrae.

The central trocar is removed from Jamshidi needle. Bone marrow does not initially flow spontaneously from the need-

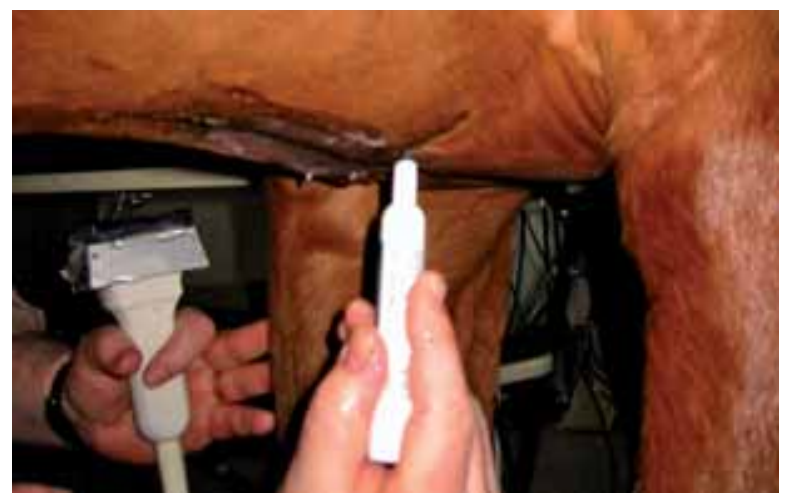

Fig 3 - Marking the intersternebral space between the two sternebrae to be aspirated with a marker pen.

Kennzeichnung des Intersternalspalts, aus dem aspiriert werden soll.

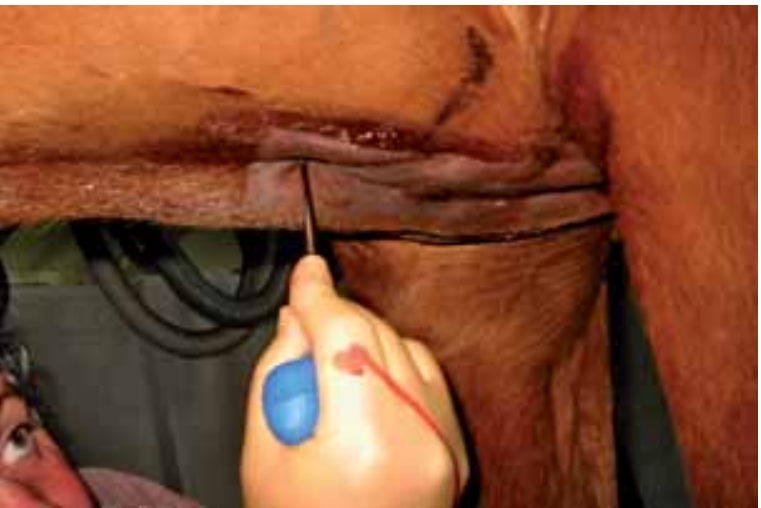

Fig 4 - Insertion of Jamshidi needle. The index finger should be placed $2 \mathrm{~cm}$ from the skin surface once the Jamshidi needle makes contact with the ventral surface of the bone to prevent over-insertion of the needle.

Einstechen der Janshidi-Kanüle. Der Zeigefinger sollte sich, wenn die Jamshidi-Kanüle Kontakt zur ventralen Knochenoberfläche hat, $2 \mathrm{~cm}$ von der Hautoberfläche befinden, um ein zu weites Eindringen zu verhindern.

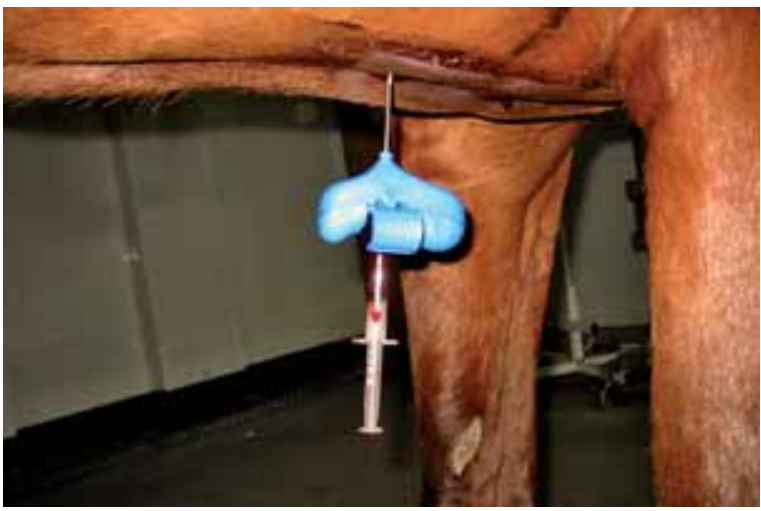

Fig 5 - Successful aspiration of bone marrow.

Erfolgreiche Aspiration von Knochenmark. 
le: it requires gentle aspiration with an attached syringe. This is usually, but only initially, associated with a small amount of discomfort to the horse, usually manifested by a slight guarding of the abdomen. Thereafter bone marrow flows easily into the syringe (fig 5) and is spontaneously shed from the needle when the needle is disconnected.

The bone marrow samples are gently agitated in the syringe to ensure adequate mixing of the anticoagulant with the

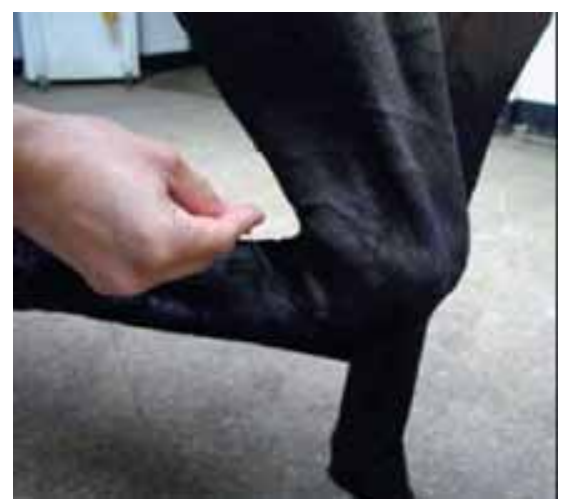

Fig 6 - The site for analgesia of the palmar and subcutaneous nerves at the subcarpal site.

Lokalisation der Leitungsanästhesie des palmaren und subcutanen Nervs im Subcarpalbereich.

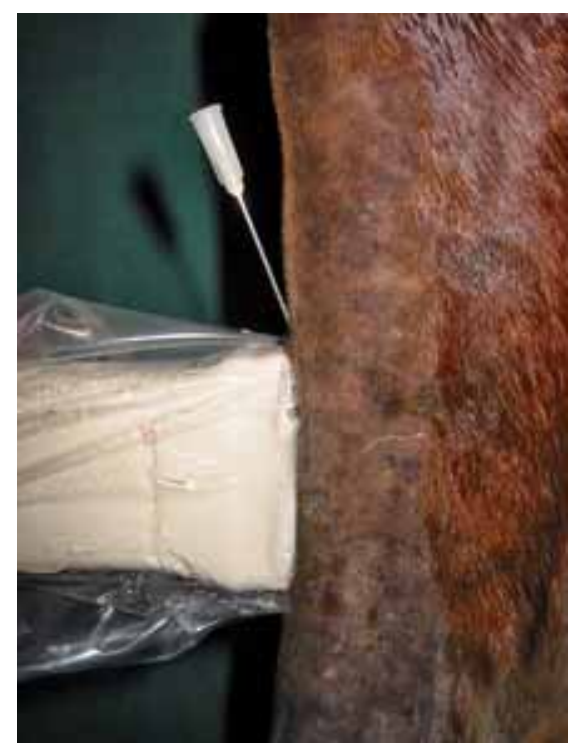

Fig 7 - Localising needle in core lesion.

Lage der Kanüle in der Kernläsion.

marrow (bone marrow clots extremely quickly). The samples are then transferred immediately to pre-chilled shipping containers. One or more samples are also obtained without heparin and transferred immediately to sodium citrate glass blood tubes. These samples are used to derive bone marrow supernatant used to resuspend mesenchymal stem cells for implantation. The second, more cranial, sternebra is then aspirated in the same fashion. Once the Jamshidi needle is withdrawn, the portals can continue to bleed but pressure is usually all that is necessary to stop this haemorrhage. Closure is unnecessary. Bone marrow can also be obtained from the tuber coxae although the yield (volume of bone marrow) is usually less.

\section{Implantation}

It is important that the cells are implanted as soon as possible after arrival, therefore implantation is best carried out in the morning and only on a Tuesday-Friday (to avoid delayed transit of the cells over a week-end).

The horse is sedated with a combination of $\alpha 2$ agonist and opiate (e.g. detomidine $\mathrm{HCl}$ and butorphanol) and the affec-

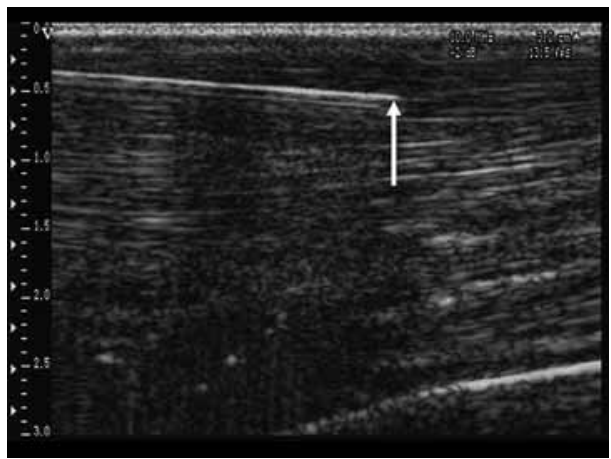

Fig 8 - Visualisation of the needle on ultrasound entering the tendon. Sonographische Darstellung der Kanüle beim Eintreten in die Sehne.

ted leg clipped to include subcarpal local anaesthetic sites. The sites are then cleaned with surgical scrub (eg chlorhexidine) and surgical spirit.

An ultrasonographic examination is performed to identify the core lesion, its extent and the appropriate site for stem cell implantation.

The local analgesia site is prepare aseptically. To ensure complete desensitisation of the skin overlying the tendon and superficial digital flexor tendon, both the palmar nerves deep to the metacarpal fascia and the subcutaneous nerve supply superficial to the fascia have to be 'blocked' on either side of the limb at the subcarpal site (fig 6). If the suspensory ligament is being treated, the palmar metacarpal nerves should also be 'blocked'. The palmar metacarpal region is then be prepared aseptically.

$2 \times 2 \mathrm{ml}$ syringes are loaded with each of the $1 \mathrm{ml}$ stem cell aliquots in a sterile fashion. The ultrasound transducer is placed in a sterile sleeve (a sterile arthroscopic camera sleeve with the end sealed can be used for this purpose) and the contact between the transducer and the skin is optimised with the use of scanning gel within the sleeve and sterile intra-site gel (or sterile ultrasound gel) on the outside. Using triangulation of a 19-21G 2 inch needle and the ultrasound transducer longitudinally 'in line' with the needle (fig. 7), the needle can be visualised entering the tendon (fig 8). Care should be taken to ensure the whole needle is visible ultrasonographically so that the end does not penetrate the deep surface of the tendon.

The first site of injection is usually the mid-point of the lesion as there is often good spread of the cells throughout the lesion after implantation in a recent injury. The stem cells are injected into 1-3 sites depending on the nature of the core lesion (more advanced healing requires more injection sites due to less spread). Accurate placement is confirmed by the 
presence of air bubbles within (and only within) the core lesion (fig 9) which will also indicate the degree of spread. After implantation, the limb is bandaged immediately to minimise subcutaneous haemorrhage and loss of injected cells from the tendon. A single peri-injection dose of intramuscular neomycin-penicillin is usually administered although may be unnecessary if the procedure is carried out in a sterile fashion.

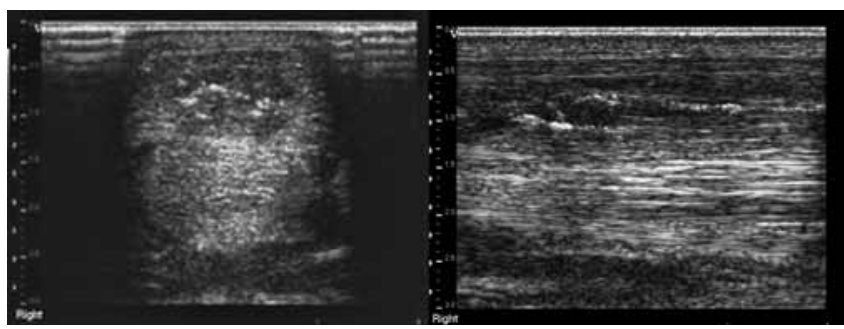

Fig 9 - After injection air bubbles from the injection are present with the core lesion in both transverse (top) and longitudinal (bottom) images.

Nach der Implantation zeigen sich in beiden Ebenen des Sonogramms Luftbläschen innerhalb der Kernläsion.

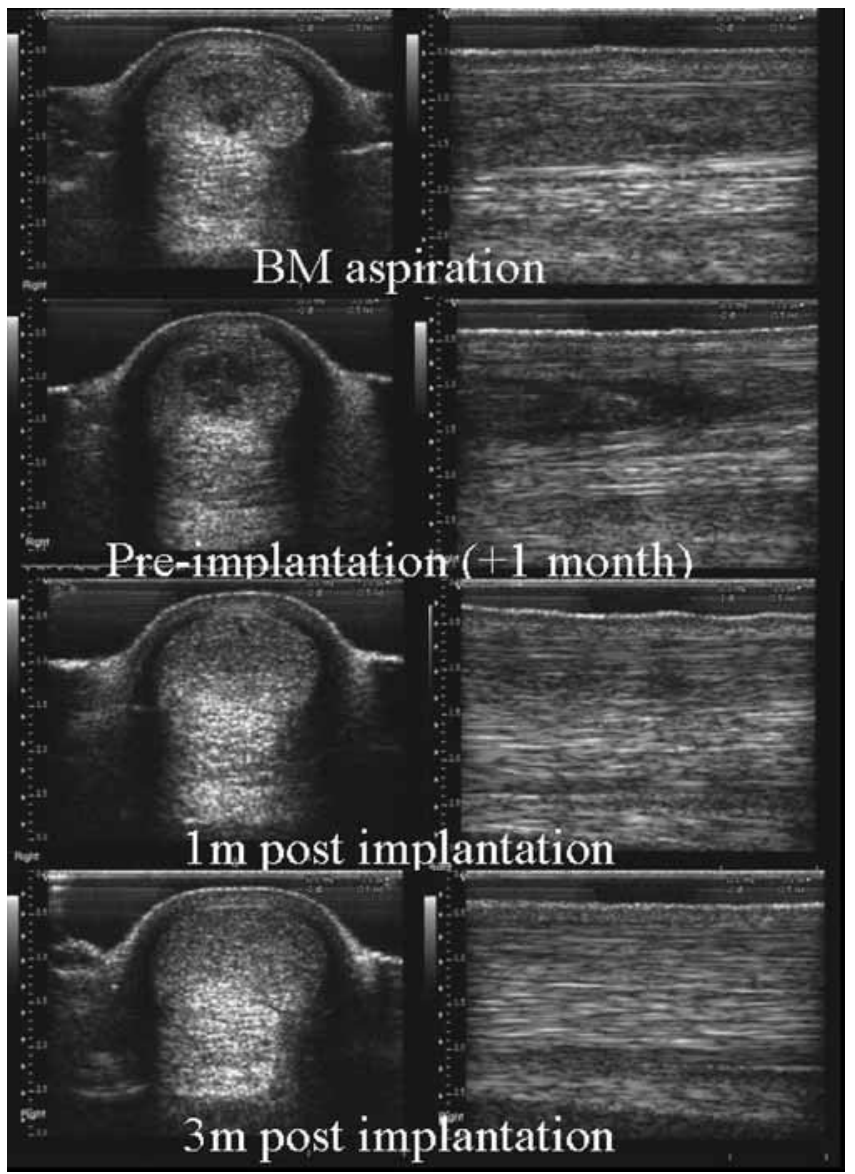

Fig 10 - Ultrasonographic outcome of a case of superficial digital flexor tendinitis treated with bone marrow-derived MSCs.

Sonographischer Verlauf eines Falles mit Tendinitis der oberflächlichen Beugesehne nach Implantation von Knochenmars-MSCs.

\section{Rehabilitation programme}

No therapy will be effective without careful attention to rehabilitation. An exercise programme that is strictly controlled and appropriately monitored will be vital for the successful management of tendon injuries. The recommended exercise programme (see table 1) consists of initial rest for 7 days (for the cells to establish themselves), followed by walking exercise for 3 months. Thereafter trotting is introduced, followed by cantering after 9 months and full work at 12 months. Regular ultrasonographic monitoring is advised at 1, 3, 6, 9, 12 months post implantation. The exercise programme after 9 months post implantation (when cantering is introduced) is usually left flexible for the owner/trainer to gradually increase the work-load back to full work over a further 3 month period. The programme may also be altered (shortened or lengthened) depending on the injury and the progression of the case.

\section{Results}

Initially, a Phase I trial was performed to ensure safety. This consisted of 6 horses with large core lesions in their SDFTs; results indicated that the technique did not cause any worsening of the injury. Furthermore, there was no reaction or enlargement of the tendon post-implantation, and no bone or cartilage was formed based on gamma scintigraphy and ultrasonography. Core lesions filled in quickly when a hypoechoic lesion was still visible at the time of implantation. The longitudinal pattern, however, remained inferior to normal tendon but improved with exercise.

Since the initial trial, in excess of 700 horses have been treated with this technique. At the most recent evaluation of clinical outcome (September 2007), 172 racehorses had been treated with $>1$ year follow-up. For National Hunt racehorses $(n=145)$, the re-injury rate was 18\% (23\% when injuries to untreated contralateral limb were included). When only those horses which had entered full training were included, the re-injury rate rose slightly to $24 \%$ (33\% with contralateral re-injuries)(see Table 2). These percentages have remained relatively constant for up to 3 years after treatment, although numbers are small for the longest follow-up. However, these data compares favourably with previous analyses for the same category of horse $(p<0.05) 56 \%$ re-injury rate for National Hunt horses (Dyson (2004) for analysis of horses used for the same discipline followed for 2 years after a return to full work. In further support for this improvement in outcome, re-injury rates for sports horses (all disciplines combined; $n=109$ with more than 1 year follow-up) was improved by a similar degree (13\% compared to $23-43 \%$ reported for different sports horse disciplines by Dyson (2004)).

The early implantation of MSCs has been supported by the analysis of the interval between injury and implantation and outcome. Successful cases (no re-injury) had an average interval between injury and implantation of 44 days while, horses suffering re-injury, this was 83 days $(p=0.0035)$. The time of implantation may be further optimised by pre-injury storage of cells.

Three cases (two with superficial digital flexor tendon injuries and one with a suspensory ligament branch injury) which have died through unrelated causes have been analysed histologically and showed excellent healing with minimal 
Table 1 - Aftercare and controlled exercise programme after stem cell therapy. Nachsorge und Rehabilitationsprogramm nach Stammzelltherapie.

\begin{tabular}{|c|c|c|}
\hline Level & Weeks after implantation & Duration and nature of exercise \\
\hline \multirow[t]{2}{*}{1} & Pre-implantation & Box rest with 10 minutes walking in hand; maintain stable bandaging \\
\hline & Week 0 & Implant cells \\
\hline 0 & 1 & Give intra-muscular antibiotics once a day for 2 more days after implantation \\
\hline 0 & 1 & Box rest; move bandage after 7 days; continue with stable bandaging \\
\hline 1 & 2 & 10 minutes walking in hand; maintain stable bandaging \\
\hline 1 & 3 & 20 minutes walking; maintain stable bandaging \\
\hline \multirow[t]{2}{*}{1} & 4 & 30 minutes walking; maintain stable bandaging \\
\hline & Week 4 & Repeat ultrasound examination \\
\hline 1 & $5-8$ & 40 minutes walking; can be ridden \\
\hline \multirow[t]{2}{*}{1} & $9-12$ & 45 minutes walking daily \\
\hline & Week 12 & Repeat ultrasound examination \\
\hline 2 & $13-16$ & 40 minutes walking and 5 minutes trotting daily \\
\hline 2 & $17-20$ & 35 minutes walking and 10 minutes trotting daily \\
\hline \multirow[t]{2}{*}{2} & $21-24$ & 30 minutes walking and 15 minutes trotting daily \\
\hline & Week 24 & Repeat ultrasound examination \\
\hline \multirow[t]{3}{*}{2} & $25-28$ & 25 minutes walking and 20 minutes trotting daily \\
\hline & $29-32$ & 20 minutes walking and 25 minutes trotting daily \\
\hline & Week 32 & Optional repeat ultrasound examination \\
\hline 3 & $33-36$ & 45 minutes exercise daily with slow canter up to 1 mile twice weekly \\
\hline 3 & $37-40$ & 45 minutes exercise daily with slow canter up to 1.5 mile twice weekly \\
\hline 3 & $41-44$ & 45 minutes exercise daily with one 3 furlong gallop three times a week \\
\hline \multirow[t]{2}{*}{3} & $45-48$ & 45 minutes exercise daily with one 6 furlong gallop three times a week \\
\hline & Week 48 & Repeat ultrasound examination \\
\hline 4 & From 48 wks & Increase exercise level gradually to full race/competition training \\
\hline
\end{tabular}

Table 2 - Clinical outcome for racehorses compared to conventional management (right hand column). $\mathrm{p}<0.05$ Klinische Ergebnisse für Rennpferde im Vergleich zur konventionellen Behandlung (rechte Spalte). $p<0,05$

\begin{tabular}{|c|c|c|c|c|c|}
\hline \multirow[t]{2}{*}{ Use } & \multicolumn{5}{|c|}{ Re-injury rate } \\
\hline & $\begin{array}{l}\text { SDFT with follow- } \\
\text { up for }>1 \text { yr }\end{array}$ & (incl. contral. limb) & $\begin{array}{l}\text { Horses returned to full } \\
\text { training; } \\
>1 \text { yr in full work } \\
\text { (incl. contralateral limb) }\end{array}$ & $\begin{array}{l}\text { Horses returned to } \\
\text { full training; } \\
>2 \text { yrs in full work } \\
\text { (incl. contral. limb) }\end{array}$ & $\begin{array}{l}\text { Horses returned to full } \\
\text { training; conventional } \\
\text { treatment; } \\
>2 \text { yrs in full work } \\
\text { (Dyson 2004) }\end{array}$ \\
\hline National Hunt & 145 & $18 \%(23 \%)$ & $23 \%(31 \%)$ & $24 \% *(35 \%)(n=17)$ & $56 \% *(n=25)$ \\
\hline Flat & 27 & $26 \%(26 \%)$ & $55 \%(55 \%)$ & $60 \%(60 \%)(n=5)$ & $66 \%(n=3)$ \\
\hline Total & 172 & $19 \%(24 \%)$ & $27 \%$ (34\%) & $32 \%(41 \%)(n=22)$ & $57 \%(n=28)$ \\
\hline
\end{tabular}

Table 3 - Clinical outcome for sports horses compared to conventional management (right hand column). Klinische Ergebnisse für Sportpferde im vergleich zur konventionellen Behandlung (rechte Spalte).

\begin{tabular}{|c|c|c|c|c|c|}
\hline \multirow[t]{2}{*}{ Use } & \multicolumn{5}{|c|}{ Re-injury rate } \\
\hline & $\begin{array}{l}\text { SDFT with follow- } \\
\text { up for }>1 \mathrm{yr}\end{array}$ & $\begin{array}{l}\text { All horses }>1 \mathrm{yr} \\
\text { post treatment } \\
\text { (incl. contralateral } \\
\text { limb) }\end{array}$ & $\begin{array}{l}\text { Horses returned to full } \\
\text { training; } \\
\geq 1 \mathrm{yr} \text { in full work } \\
\text { (incl. contralateral limb) }\end{array}$ & $\begin{array}{l}\text { Horses returned to full } \\
\text { training; } \\
\frac{\geq 2 \text { yrs in full work }}{\text { (incl. contralateral }} \\
\text { limb) }\end{array}$ & $\begin{array}{l}\text { Horses returned to full } \\
\text { training; conventional } \\
\text { treatment; } \\
\geq 2 \text { yrs in full work } \\
\text { (Dyson, 2004) }\end{array}$ \\
\hline Sports horses & 109 & $6 \%(9 \%)$ & $8 \%(13 \%)$ & $\begin{array}{l}13 \%(20 \%) \\
(n=15)\end{array}$ & $\begin{array}{l}23-43 \%(n=107) \\
43 \%(\text { eventers; } n=79)\end{array}$ \\
\hline
\end{tabular}


inflammatory cells, and crimped organised collagen fibers. In contrast, a contralateral untreated suspensory ligament injury in one of these horses, which was clinically silent at the time of implantation, showed persistent inflammatory cells and poorly organised collagen fibers (Mountford et al 2006).

A more limited number of cases have been treated with injuries to other tendons and ligaments. For lesions present within a tendon sheath, the implantation is done after tenoscopic evaluation to ensure that there are no surface defects through which the cells could leak.

\section{Conclusions}

There are thus some encouraging aspects to this technology although definitive proof of efficacy is still lacking which is essential before full confidence in the technology can be achieved. Furthermore there have been no direct comparisons between the two techniques currently available for use commercially. It must be remembered that there are still considerable gaps in our knowledge although the technology is developing rapidly. Although cell-based therapies are likely to be another instrument for tackling orthopaedic disease in the future, it is also likely that we will need to be selective in choosing the right clinical cases. It is also hoped that experience gained from treating clinical cases in horses will provide sufficient supportive data to encourage the translation of this technology into the human field where larger randomised control trials will lead to better evidencebased medicine.

\section{Acknowledgements}

The author would like to thank all the treating veterinarians from which much of the clinical data was obtained in conjunction with MedCell Bioscience Ltd. (formerly VetCell Bioscience Ltd.). In particular, the author acknowledges the assistance of Prof. Allen Goodship, Prof Gordon Blunn and Mr. Greg McGarrell with the development of the technique and Ms. Fiona Cunnington, Mr. David Mountford, and Mr. Greg McGarrell of MedCell Bioscience Ltd. for the analysis of the clinical data.

\section{References}

Dyson S. J. (2004) Medical management of superficial digital flexor tendinitis: A comparative study in 219 horses (1992-2000). Equine Vet. J. 36: 415

Mountford D. R., Smith R. K. W. and Patterson-Kane J. C. (2006) Mesenchymal stem cell treatment of suspensory ligament branch desmitis: post mortem findings in a 10 year old Russion Warmblood gelding - a case report. Pferdeheilkunde 22, 559-563

Smith R. K., Korda M., Blunn G. W. and Goodship A. E. (2003) Isolation and implantation of autologous equine mesenchymal stem cells from bone marrow into the superficial digital flexor tendon as a potential novel treatment. Equine Vet J, 35, 99-102

Prof. Roger K. W. Smith MA VetMB PhD DEO DipECVS MRCVS Professor of Equine Orthopaedics

The Royal Veterinary College

Hawkshead Lane, North Mymms, Hatfield, Herts. AL9 7TA, UK rksmith@rvc.ac.uk 